\title{
Effect on the Enzymatic Hydrolysis of Lipids from Dairy Wastewater by Replacing Gum Arabic Emulsifier for Sodium Chloride
}

\author{
Adriano Aguiar Mendes* and Heizir Ferreira de Castro \\ Departamento de Engenharia Química; Faculdade de Engenharia Química de Lorena; C. P. 116; \\ heizir@dequi.faenquil.br; 12600-970; Lorena-SP - Brasil
}

\begin{abstract}
The objective of this work was to evaluate the replacement of Gum Arabic for sodium chloride to reduce fat and organic contents in dairy wastewater using two low cost commercially available lipase preparations from animal source (Kin Master - LKM and Nuclear- LNU). The best performance was achieved when lipase Nuclear (LNU) was used as catalyst. In addition, this lipase preparation has also lower cost, which makes its use a quite promising technique for reduction of suspended solids as proteins and lipids contents found in wastewater generated by dairy industries.
\end{abstract}

Key words: Lipases, hydrolysis, emulsifier and biodegradability

\section{INTRODUCTION}

Lipids are an important component in wastewater that causes severe environment pollution. It can form oil films on water surfaces, preventing the diffusion of oxygen from air into water, leading to the death of many forms of aquatic life. Aggregates formed by oil droplets and other particles present in wastewater can also block water drainage lines. The application of anaerobic reactors to treat lipids-rich wastewater can cause granular sludge flotation and wash-out, inhibition of methanogenic activity and decrease the concentration of adenosine triphosphate (ATP) (Perle et al., 1995; Mendes, 2004).

To cope with these negative effects on the waterstream treatment, several strategies for removing these lipid residues at the head of the plant are proposed. Among these, the alternative of using specific enzymes (lipases) has, recently, potentially gained more attention because of stringent environmental regulations and clean and friendly application of enzymes (Gandhi, 1997; Mendes et al, 2005). Lipases (triacylglycerol acylhydrolases, E.C. 3.1.1.3) are enzymes that catalyze the hydrolysis of triacylglycerols to glycerol and free fatty acids at the water-lipid interface and the reverse reaction in non-aqueous media (Castro et al., 2004). These enzymes showed potential applications in degrading oil and fats in wastewater generated by dairy industries, slaughterhouses, edible oils, fat refineries and others (Mendes et al, 2005; Pereira, 2004).

Emulsifying agents have been systematically used in measurements of lipase activity, mainly to increase the lipid-water interfacial area, which, in turn, enhances the observed rates of lipasecatalyzed reaction (Rocha, 1999). These compounds, also denominated surfactants, are

\footnotetext{
${ }^{*}$ Author for correspondence
} 
amphiphilic molecules and can be classified as ionic (anionic and cationic), non-ionic and amphoteric (Rocha, 1999). From the available emulsifying agents, Gum Arabic (GA) is the most commonly used for long chain fatty acids lipids such as natural olive oil, given emulsions which can be stored for several weeks (Tiss et al., 2002). It has been generally been assumed that the GA was simply an emulsifying agent stabilizing emulsions without interfering with the lipase assay itself. However, the presence of high GA concentrations drastically reduced the lipase activity. Tiss et al. (2002) investigated the GA effects on the interfacial binding and activity of human pancreatic lipase (HPL) using trioctanoglycerol emulsion and related that the inhibition of HPL by GA was due to the lipase desorption from the interface water/ oil.

GA consists mainly of polysaccharide chains, including glucuronic acid units (Whistler, 1993). In the normal ionized form at neutral $\mathrm{pH}$ levels, these carboxyl groups of uronic acid will be deprotonated and thus confer to the emulsion a global negative surface charge. In addition, during the lipids hydrolysis the $\mathrm{pH}$ at the lipid/ lipase interface becomes lower than in the bulk solution due to the negatively charged of long chain fatty acids on the solid surface attracting hydrogen ions (Brockerhoff and Jensen, 1974). Therefore, $\mathrm{NaCl}$ addition is generally recommended to neutralize the negative $\mathrm{pH}$ gradient at the interface, where the enzyme/ substrate complex is formed. This was also verified in the studies performed by Entressangles and Desnuelle (1968), in which the hydrolysis of triacetin supplemented with sodium chloride $(0.1 \mathrm{M})$ by porcine pancreatic lipase showed to reduce the value of the critical micelle concentration, with a corresponding increase in the size of micelles, allowing to attain higher lipase activity.

Although emulsifying agent is found to be essential for the hydrolysis performance, its presence in the reaction medium may slow down the production of methane gas and decrease the percentage of COD removal (Pereira, 2004). Therefore, the aim of this study was to evaluate the effects of replacing non-ionic GA by sodium chloride in the hydrolysis of rich-lipids wastewater from dairy industries using preparations of porcine pancreas lipase commercially available in Brazil Kin Master (LKM) and Nuclear (LNU). These preparations have low cost $(\mathrm{LKM}=260 \mathrm{US} \$ / \mathrm{kg}$ and $\mathrm{LNU}=70 \mathrm{US} \$ / \mathrm{kg}$ ), which may suggest their suitability for waste treatment. Moreover, these lipase preparations contain others hydrolytic enzymes as proteases and $\alpha$-amylases that can be also beneficial to the process, since wastewater from dairy industries contain besides lipids, protein and starch compounds.

Experiments were carried out using a factorial design that considered the influence of the variables and its interactions in the yield of the process with reduction of time, materials and resources (Box et al., 1978).

\section{MATERIALS AND METHODS}

\section{Materials}

Low cost lipase preparations (porcine pancreas) commercially available in Brazil - Kin Master (LKM, Passo Fundo-RS) and Nuclear (LNU, São Paulo) were used. Raw wastewater from dairy industries (Maringa Corporation, located at São Paulo-Brazil) collected before the flotation tank was used for all the experiments. Aliquots were stocked in a freezer $\left(-4^{\circ} \mathrm{C}\right)$ and characterized. All chemicals were analytical grade.

\section{Enzymatic hydrolysis}

Hydrolysis reactions were carried out in $125 \mathrm{~mL}$ round flasks containing $100 \mathrm{~g}$ of crude wastewater and known amount of enzyme $(0.3 \%$ w/v), emulsifying agent $(\mathrm{GA}, 3.0 \% \mathrm{w} / \mathrm{v})$ or sodium chloride $(0-7.0 \mathrm{mM})$ and $\mathrm{pH}$ adjustment to 8.0 with $1 \mathrm{M} \mathrm{NaOH}$ solution (Mendes and Castro, 2004). The contents were agitated with a magnetic stirrer at a constant speed of $200 \mathrm{rpm}$. Reactions were carried out at 37 and $40^{\circ} \mathrm{C}$ for LNU and LKM lipases, respectively, under atmospheric pressure during 6-24 h. At intervals, samples $(2.0 \mathrm{~g})$ were removed from the reactor through a syringe, weighed and transferred to $100 \mathrm{~mL}$ conical flask. Ten milliliters of 50:50 v/v mixture of acetone in ethanol were added to the sample to denature the enzyme, thus effectively freezing the reaction. Phenolphthalein indicator was added and the mixture was titrated with standard $0.02 \mathrm{~N}$ potassium hydroxide solution. The formation of free fatty acids was used to monitor the reaction evolution. Protein and glycerol concentrations were also determined at the end of the enzymatic treatment. 


\section{Experimental design}

A $2^{2}$ full factorial central composite design leading to nine sets of experiments was performed. The range and levels of the variables investigated in this study are given in Table 1. The fatty acids concentration was taken as the response of the design experiment. The "Statistic" software (version 5.0) was used for regression and graphical analyses of the obtained data. The statistical significance of the regression coefficients was determined by Student's test, the model equation was determined by Fischer's test and the proportion of variance explained by the model was given by the multiple coefficient of determination, $\mathrm{R}^{2}$.

Table 1 - Factor levels used according to the $2^{2}$ full factorial central composite design

\begin{tabular}{l|rrr}
\hline Variables & \multicolumn{3}{|c}{ Levels } \\
\cline { 2 - 4 } & -1 & 0 & +1 \\
\hline $\mathrm{x}_{1}: \mathrm{NaCl}(\mathrm{mM})$ & 0 & 3.5 & 7.0 \\
$\mathrm{x}_{2:}$ lipase preparation & LKM & - & LNU \\
\hline
\end{tabular}

Table 2 - Characteristics of the dairy wastewater used in this study

\begin{tabular}{l|c}
\multicolumn{1}{c}{ Parameter } & Concentration value \\
\hline Total solids (mg/L) & 6.51 \\
Acidity & 0.26 \\
Value of saponification & 155.13 \\
Free fatty acids (\%) & 0.05 \\
Lipids (mg/L) & 1530 \\
pH & 6.69 \\
COD (mg/L) & 15000 \\
Proteins (mg/L) & 3517 \\
Reducing sugars (mg/L) & 449 \\
Glycerol (\%) & 0.25 \\
Density (g/cm $\left.{ }^{3}\right)$ & 0.995 \\
Capric acid (\%) & 2.40 \\
Lauric acid (\%) & 3.21 \\
Myristic acid (\%) & 13.9 \\
Palmitic acid (\%) & 39.2 \\
Stearic acid (\%) & 16.8 \\
Oleic acid $(\%)$ & 21.2 \\
\hline
\end{tabular}

\section{Analytical Methods}

Lipids were determined by Soxhlet extraction using hexane as a solvent at $70^{\circ} \mathrm{C}$, according to the procedure described in the Standard Methods of Water and Wastewater Examination (APHA, 1995). Free fatty acids concentration was determined by titration of aliquots dissolved in 10 $\mathrm{mL}$ ethanol p.a., using $0.02 \mathrm{M} \mathrm{KOH}$ alcoholic solution. The acidity was determined by titration, using $0.1 \mathrm{~N} \mathrm{NaOH}$ solution, recording the volume required to neutralize the level of free fatty acids in one gram of sample and expressing the results as percentage of free fatty acids. Chemical Oxygen Demand (COD) was measured as described in the Standard Methods (APHA, 1995). Total reducing sugars concentrations were determined using 3,5 Dinitrosalicylic acid reagent (DNS) method (Martelli and Panek, 1968). Protein concentration was determined using the Lowry's method (Lowry et al., 1951). Glycerol was determined according to the methodology proposed by Coks and Van Rede (1966). The saponification value was calculated from the composition in fatty acids that corresponded to milligrams of potassium hydroxide required to neutralize the free fatty acids liberating from the hydrolysis of $1 \mathrm{~g}$ of the sample (Moretto e Fett, 1998). Fatty acids distribution in the effluent was assayed by gas chromatography (Shimadzu, Model CG 17A) using capillary column DB-1 (30 m X $0.25 \mathrm{~mm})$. 
Samples were previously treated according to methodology described by Metcalfe et al. (1966).

\section{RESULTS AND DISCUSSION}

\section{Characterization of dairy wastewater}

The dairy industry produces many different products such as pasteurized-, condensed-, skimmed- and powdered-milk, yogurt, butter, different types of desserts and cheeses and sometimes cheese whey. Wastewaters from the dairy industry are generally produced in an intermittent way, and the flow and characteristics change from one factory to another depending on the kind of systems and the methods of operation (Vidal et al., 2000). The main contributors to the organic load of these wastewaters are fats, sugars and proteins (Perle et al., 1995; Mendes and Castro, 2004). The features and characteristics of the dairy wastewater used in this study are given in Table 2.

Concentrations for proteins, sugars and organic matter (COD) were lower than the values reported in the literature (Lyberatos et al., 1997), but lipid concentrations $(1530 \mathrm{mg} / \mathrm{L})$ were about 2.5 times higher than the normally found in dairy wastewater. Such high concentration was probably due to long chain fatty acids coming from the product manufacture in addition to the fatty acids from surfactants used in the cleaning stages (floors, tubes and gallons). The surfactants normally used for this purpose are soaps (sodium salts of long chain fatty acids from vegetable oils or animal fats). Concerning the fatty acids distribution, the crude wastewater contained high concentration of palmitic acid (>30\%), followed by oleic acid $(>20 \%)$, stearic $(>10 \%)$ and myristic $(>10 \%)$.

Hydrolysis of wastewater emulsified with gum arabic

The hydrolysis was performed as previously established for cheese whey (Mendes and Castro, 2004). Figs 1 and 2 showed that the formation rate of fatty acids was higher at the first $6 \mathrm{~h}$ for both lipase preparations LKM $(2.60 \pm 0.23 \mathrm{mM} / \mathrm{h})$ and LNU $(2.76 \pm 0.04 \mathrm{mM} / \mathrm{h})$. After this period, the rate was reduced only for LKM lipase, attained fatty acids concentrations in the order of $18.02 \pm$ 0.52 , after $24 \mathrm{~h}$ reaction. For LNU lipase, fatty acids concentration was $38.27 \pm 0.94 \mathrm{mM}$. The hydrolysis rates achieved in this work for both lipases were higher than that one attained for cheese whey $(23.1 \%)$, probably, due to the high glycerol concentration contained in cheese whey $(2.74 \%)$. High glycerol concentration may shift the reaction equilibrium favoring the reserve direction (ester synthesis).

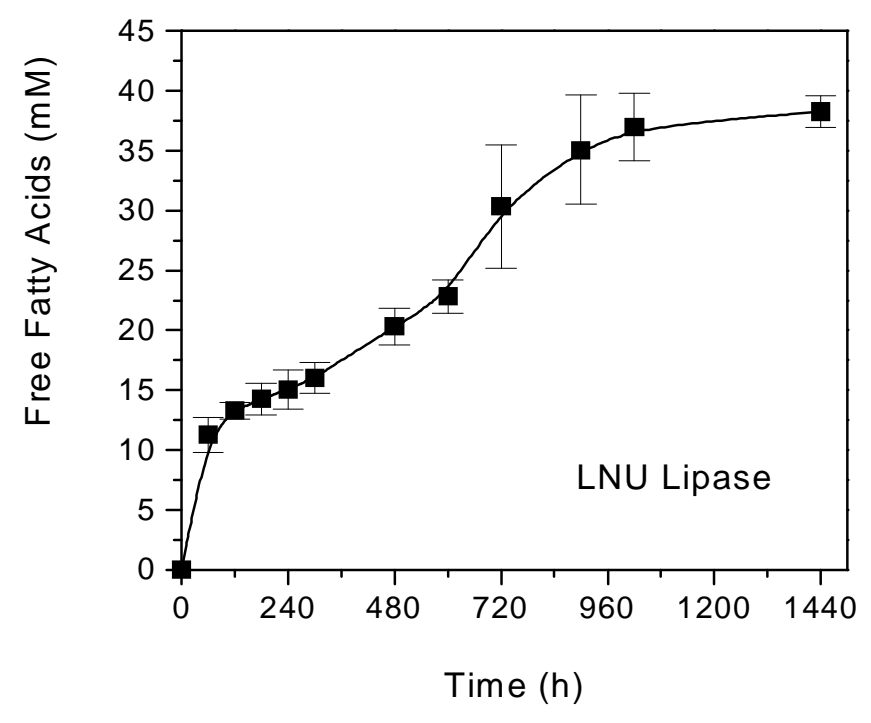

Figure 1 - Profile of free fatty acids formed in the hydrolysis of the wastewater emulsified with GA ( $3 \% \mathrm{w} / \mathrm{w})$ by LNU lipase $\left(24 \mathrm{~h}, 37^{\circ} \mathrm{C}, 200 \mathrm{rpm}, \mathrm{pH}=8.0\right)$. 


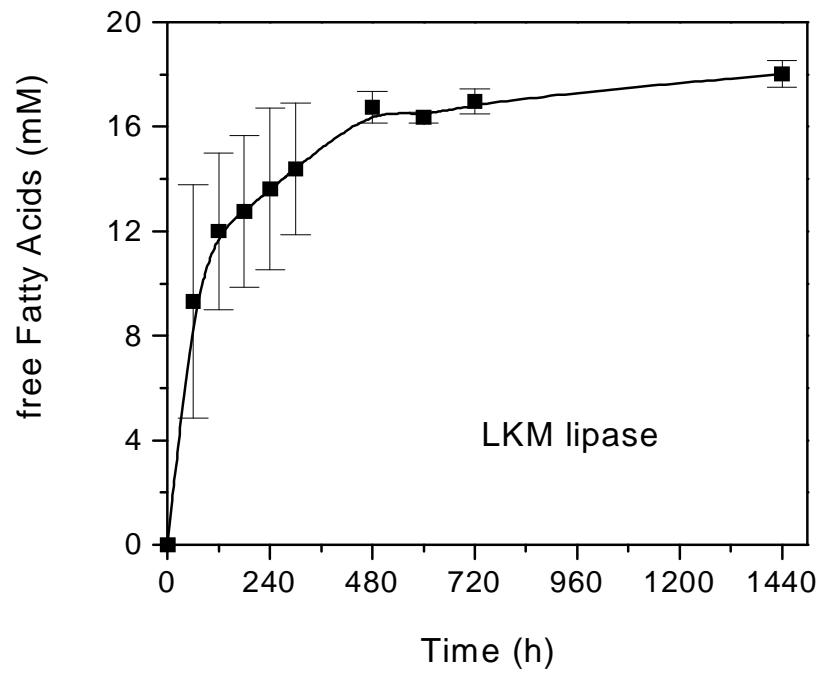

Figure 2 - Profile of free fatty acids formed in the hydrolysis of the wastewater emulsified with GA (3\% w/w) by LKM lipase $\left(24 \mathrm{~h}, 40^{\circ} \mathrm{C}, 200 \mathrm{rpm}, \mathrm{pH}=8.0\right)$.

Table 3 - Composition of wastewater pretreated with LKM and LNU lipases preparations

\begin{tabular}{l|c|c|c|c}
\hline \multirow{2}{*}{ Lipase } & \multirow{2}{*}{$\begin{array}{c}\text { Glycerol } \\
(\boldsymbol{\%})\end{array}$} & \multirow{2}{*}{$\begin{array}{c}\text { Fatty acids } \\
(\mathbf{m M})\end{array}$} & \multicolumn{2}{|c}{$\begin{array}{c}\text { Hydrolysis percentage } \\
\text { (\%) }\end{array}$} \\
\cline { 4 - 5 } & LKM & & Lipids & Proteins \\
LNU & $24.0 \pm 1.0$ & $18.0 \pm 0.5$ & 30.5 & 17.4 \\
& $30.0 \pm 8.0$ & $38.3 \pm 0.9$ & 38.9 & 22.0 \\
\hline
\end{tabular}

Further information was obtained by determining the protein and glycerol concentrations as shown in Table 3. The enzymatic treatment also decreased the protein levels in the wastewater attaining average values of 17.4 and $22.0 \%$, for LKM and LNU lipases, respectively. The main compounds obtained in the protein hydrolysis have low molecular weight such as peptides and amino acids (Perle et al., 1995), which can help the wastewater anaerobic digestion.

Rooney and Weatherley (2001) evaluated the influence of formed glycerol in the hydrolysis of sunflower oil (at proportion 3:2 water-oil) using Candida rugosa lipase under consecutive batches. The removal of aqueous phase rich in glycerol by centrifugation increased the hydrolysis rate from 85 to $100 \%$. However, for the enzymatic hydrolysis of wastewater rich-lipids, this step is not required. Moreover, glycerol was found to have non-inhibitory effect on the bacterial methanogenic activity as described by Perle et al.
(1995). These authors evaluated the effect of the products formed during fat-milk hydrolysis on the concentration of adenosine triphosphate (ATP) and methanogenic activity using the main long chain fatty acid containing in industrial wastewater (oleic acid) and non-acclimated anaerobic biomass. They found that formed glycerol did not inhibit the methanogenic activity of the anaerobic sludge and increased adenosine triphosphate (ATP) and methane $\left(\mathrm{CH}_{4}\right)$ concentrations.

To test the GA effect on the biodegradability of the treated wastewater, samples obtained at the end of the enzymatic hydrolysis were analyzed for organic matter (COD). Results indicated minimal changes on the organic matter level for both lipases (data not shown). Similar results were described by Mendes and Castro (2004) when testing the enzymatic hydrolysis of cheese whey previously emulsified with high GA concentration (7\% w/w). In addition, Pereira (2004) also suggested that the GA addition in the wastewater 
had negative effects during the anaerobic biodigestion of slaughterhouses previously treated with microbial lipase from $C$. rugosa. Recalcitrant compounds found in the GA could be related to lower the organic matter removal in the biodegradability assays.
Experimental design

To evaluate the effect of replacing GA for sodium chloride on the lipids hydrolysis a $2^{2}$ full factorial central composite design was carried out. Table 4 shows the experiment matrix together with the results obtained. The fatty acids concentrations varied from 0 to $17.97 \mathrm{mM}$ and the highest value (run 4) was reached at high $\mathrm{NaCl}$ levels $(7 \mathrm{mM})$ when LNU was used as enzymatic preparation.

Table 4 - Experimental design and results according to the $2^{3}$ full factorial central composite design

\begin{tabular}{c|c|c|c|c|c}
\hline Run & $\mathbf{x}_{\mathbf{1}}$ & $\mathbf{x}_{\mathbf{2}}$ & $\begin{array}{c}\mathbf{N a C l} \\
(\mathbf{m M})\end{array}$ & Lipase & $\begin{array}{c}\text { Fatty acids* } \\
(\mathbf{m M})\end{array}$ \\
\hline 1 & -1 & -1 & 0 & LKM & 15.63 \\
2 & +1 & -1 & 7 & LKM & 17.15 \\
3 & -1 & +1 & 0 & LNU & 15.81 \\
4 & +1 & +1 & 7 & LNU & 17.97 \\
5 & -1 & 0 & 0 & 0 & 0 \\
6 & +1 & 0 & 7 & 0 & 0 \\
7 & 0 & -1 & 3.5 & LKM & 17.16 \\
8 & 0 & +1 & 3.5 & LNU & 17.10 \\
9 & 0 & 0 & 3.5 & 0 & 0 \\
\hline
\end{tabular}

*Concentrations after $6 \mathrm{~h}$ reaction

Table 5 - Estimated effects, standard errors and Student's $t$ test for the hydrolysis rate according to the $2^{2}$ full factorial central composite design

\begin{tabular}{l|r|c|c|c}
\hline \multicolumn{1}{c|}{ Factors } & Effects & Standard error & t-value & $\mathbf{p}$ \\
\hline $\mathrm{x}_{1}$ & 1.22 & \pm 0.44 & 2.7403 & 0.0337 \\
$\mathrm{x}_{2}{ }^{2}$ & 33.61 & \pm 0.77 & 43.351 & 0.0000 \\
\hline
\end{tabular}

The experiment results showed in Table 4 were used to estimate the main variable effects and their interactions. According to the Student's $t$-test results (Table 5), the most important factor was the lipase preparation $\left(\mathrm{x}_{2}{ }^{2}\right)$, which had a highly significant effect (99\% of confidence level). The effect of $\mathrm{NaCl}\left(\mathrm{x}_{1}\right)$ was also significant $(p<0.05)$. The results also suggested that regardless the lipase preparation, runs using $\mathrm{NaCl}$ gave higher fatty acids concentrations.

A different behavior was reported by Masse et al. (2001), in which the supplementation of the 1 $\mathrm{g} / \mathrm{L} \mathrm{NaCl}$ to slaughterhouse wastewater receiving between 100 and $500 \mathrm{mg} / \mathrm{L}$ of pancreatic lipase was found to have no beneficial effect. According to these authors, residual $\mathrm{NaCl}$ or other salts in the slaughterhouse wastewater masked the benefit of adding $\mathrm{NaCl}$. In the slaughterhouse wastewater, sodium concentration was estimated in the range of $272 \pm 85 \mathrm{mg} / \mathrm{L}$ and this wastewater also contained approximately $50 \mathrm{mg} / \mathrm{L}$ of calcium and $20 \mathrm{mg} / \mathrm{L}$ of magnesium, ions which bound inhibitory long chain fatty acids and remove them by forming calcium or magnesium salts (Brockerhoff and Jensen, 1974). Ions concentrations in dairy wastewater were not reported in the literature.

The main effects were fitted by multiple regression analysis to a linear model, and the best fitting response function can be described by Eq. (1).

$$
\mathrm{Y}=0.61 \mathrm{x}_{1}+16.80 \mathrm{x}_{2}^{2}
$$

where: $\mathrm{Y}$ is the value predicted for the fatty acids $(\mathrm{mM}), \mathrm{x}_{1}$ and $\mathrm{x}_{2}$ represent the coded values for $\mathrm{NaCl}$ concentration and type of lipase preparation, respectively.

The statistical significance of this model was evaluated by the F-test (Table 6), which revealed that this regression was statistically significant at a 
99\% probability level. The model did not show lack of fit and the determination coefficient $\left(\mathrm{R}^{2}=0.99\right)$ indicated that the model could explain $99 \%$ of the variability.

According to this study, the maximum fatty acid concentration $(18.19 \mathrm{mM})$ could be obtained, working at the highest level for both variables, that is, lipase preparation (LNU) and sodium chloride (7.0 mM). Hydrolysis runs were performed twice under the optimum conditions predicted by the model (Table 7), and the average value for fatty acids formation was $17.97 \mathrm{mM}$ (Hydrolysis rate= $26.2 \%$ ), which confirmed the prediction made by the same model.

Table 6 - Analysis of variance (ANOVA) for the model regression that represents the fatty acids obtained in the wastewater hydrolysis

\begin{tabular}{lr|r|r|r|r}
\hline \multicolumn{1}{c}{ Effects } & SS & DF & MS & F-value & p \\
\hline $\mathrm{x}_{1}{ }^{2}$ & 2.257 & 1 & 2.257 & 7.512 & 0.033 \\
$\mathrm{x}_{2}{ }^{2}$ Residual & 564.7 & 1 & 564.7 & 1879.35 & 0.000 \\
Total & 1.80 & 6 & & & \\
\hline
\end{tabular}

$\mathrm{R}^{2}=0.9968$

$\mathrm{SS}=$ Sum of Squares;

$\mathrm{DF}=$ Degree of Freedom; MS = Mean Square

Table 7 - Composition of wastewater pretreated with LNU lipase preparation

\begin{tabular}{c|c|c|c}
\hline \multirow{2}{*}{$\begin{array}{c}\text { Glycerol } \\
(\boldsymbol{\%})\end{array}$} & \multirow{2}{*}{$\begin{array}{c}\text { Fatty acids } \\
(\mathbf{m M})\end{array}$} & \multicolumn{2}{|c}{$\begin{array}{c}\text { Hydrolysis percentage } \\
(\boldsymbol{\%})\end{array}$} \\
\cline { 3 - 4 } & & Lipids & Proteins \\
\hline 14.4 & 17.97 & 26.2 & 20.7 \\
\hline
\end{tabular}

Although better enzyme performance in terms of glycerol and fatty acids formation was found for emulsified (GA) wastewater, higher organic load removal was achieved for no-emulsified $(\mathrm{NaCl})$ wastewater, decreasing about $42.8 \%$ the COD levels, which could facilitate further biodigestion step. In addition, at industrial scale enzymatic pretreatment without GA addition would be more attractive economically since less operation steps would be need.

According to the results achieved in this work, LNU lipase was selected for further optimization of the hydrolysis step. Besides given better performance on the hydrolysis of lipids and proteins, this enzymatic preparation also had lower cost (US\$ 70.00/ kg), given the best cost/ profit ratio (US\$ 0.21 per liter of treated wastewater) when comparison was made with the LKM lipase performance (US\$ 0.82 per liter of treated wastewater).

\section{CONCLUSIONS}

The application of lipases in treating lipid-rich wastewater is very limited practically. This limitation is probably due to the high cost of lipases. Even though there is a potential for application of lipase in routine wastewater treatment, the process is perhaps very expensive compared to some high value application of lipase as pharmaceutical and fine chemical uses.

In this work two cheap commercially available lipase preparations from animal source (Kin Master - LKM and Nuclear - LNU) were used for decreasing fat and organic contents in dairy wastewater. Gum Arabic and sodium chloride was tested as emulsifying agent to give proper conditions for interface activation where the lipase reaction occurs. The conditions that maximized both the lipids breakdown and organic matter reduction were attained when the enzyme LNU was used in no-emulsified wastewater. Further experiments are necessary to evaluate the biodegradability of the pretreated wastewater. 


\section{ACKNOWLEDGMENTS}

The authors gratefully acknowledge the financial assistance of $\mathrm{CNPq}$ (Conselho Nacional de Desenvolvimento Científico- Programa CT-Hidro) and FAPESP, Brazil.

\section{RESUMO}

O objetivo deste trabalho foi verificar o efeito do cloreto de sódio em substituição à goma arábica, na redução do teor de lipídeos presentes em efluentes de laticínios empregando duas preparações de lipases pancreáticas adquiridas no mercado nacional (Kin Master - LKM e NuclearLNU). A preparação enzimática LNU foi mais eficiente na redução de proteínas e lipídeos, mostrando ser uma alternativa promissora para uso no pré-tratamento de águas residuárias com elevado teor desses compostos.

\section{REFERENCES}

Box, G. E. P.; Hunter, W. G. and Hunter, J. S. (1978), In-Statistics for Experimenters: An Introduction to Design, Data Analysis and Model Building. Wiley and Sons Inc. New York.

Brockerhoff, H. and Jensen, R. G. (1974), In-Lipolytic Enzymes. New York: Academic Press.

Castro, H. F.; Mendes, A. A.; Santos, J. C. and Aguiar, C. L. (2004), Modificação de óleos e gorduras por biotransformação. Quim. Nova, 27, 146-156.

Coks, L. V. and Van Rede, C. (1996), In- Laboratory handbook for oils and fats analysis. London : Academy Press.

Entressangles, B. and Desnuelle, P. (1968), Action of pancreatic lipase on aggregated glyceride molecules in an isotropic system. Biochim. Biophys. Acta, 159, 285-295.

Gandhi, N. N. (1997), Applications of lipases. J. Am. Oil Chem. Soc., 74, 621-634.

Lowry, O. H.; Rosebrough, N. J.; Farr, A. L. and Randall, R. J. (1951), Protein measurement with the Folin phenol reagent. J. Biol. Chem., 193, 265-275.

Lyberatos, G.; Gavala, H. N. and Stamatelatou, A. (1997), An integrated approach for management of agricultural industries wastewater. Nonlin. Anal, Theory, Meth. Appl., 30, 2341-2351.

Masse, L.; Kennedy, K. J. and Chou, S. (2001), Testing of alkaline and enzymatic pretreatment for fat particles in slaughterhouses wastewater. Bioresour. Technol., 77, 145-155.
Martelli, H. L. and Panek, A. D. (1968), Dosagem de glicídeos redutores pelo ácido 3,5 dinitrosalicílico. Bioquímica Experimental. Rio de Janeiro : Ao Livro Técnico.

Mendes, A. A. and Castro, H. F. (2004), Redução do teor de lipídeos presentes em efluentes das indústrias de produtos lácteos empregando lipases pancreáticas. Rev. Saúde Amb., 5, 31-39.

Mendes, A. A. (2004), Avaliação da biodegradabilidade anaeróbia de efluentes com alto teor de lipídeos previamente tratados com enzimas hidrolíticas. MSc Dissertation, Chemical Engineering College of Lorena, Lorena, Brazil

Mendes, A. A.; Castro, H. F.; Pereira, E. B. and Furigo Jr., A. (2005), Aplicação de lipases no tratamento de águas residuárias com elevado teor de lipídeos. Quim. Nova, 28, 296-305.

Metcalfe, L. D.; Schmitz, A. A. and Pelka, J. R. (1966), Rapid preparation of fatty acid esters from lipids for gas chromatographic analysis. Anal. Chem., 38, 514-515.

Moretto, E. and Fett, R. (1998), Tecnologia de Óleos e Gorduras Vegetais na Indústria de Alimentos. Florianópolis : UFSC. 150 pp.

Pereira, E. B. (2004), Tratamento enzimático para remoção de gorduras dos resíduos gerados por indústrias de produtos avícolas. PhD Thesis, Federal University of Santa Catarina, Florianópolis, Brazil.

Perle, M.; Kimchie, S. and Shelef, G. (1995), Some biochemical aspects of the anaerobic degradation of dairy wastewater. Wat. Res., 29, 1549-1554.

Rocha, J. M. S. (1999), Aplicações de agentes tensoactivos em biotecnologia. Bol. Biotecnol., 64, 5-11.

Rooney, D. and Weatherley, L. R. (2001), The effect or reaction condition upon lipase catalysed hydrolysis of high oleate sunflower oil in a stirred liquid-liquid reactor. Process Biochem., 36, 947-953.

Standard Methods (1995), for Examination of Water and Wastewater, $19^{\text {th }}$ ed. Publication Office American Public Health Association, Washington. APHA, AWWA, WEF.

Tiss, A.; Carriéri, F.; Douchet, I.; Patkar, S.; Svendsen A. E. and Verger, R. (2002), Interfacial binding and activity of lipases at the lipid-water interface: effects of gum arabic and surface pressure. Coll. Surf. B: Bioint., 26, 135-145.

Vidal, G.; Carvalho, A.; Méndez, R. and Lema, J. M. (2000), Influence of the content in fats and proteins on the anaerobic biodegradability of dairy wastewater. Bioresour. Technol., 74, 231-239.

Whistler, R. L. (1993), Industrial Gums. New York : Academic Press. 